

\section{DISCLAIMER}

This report was prepared as an account of work sponsored by an agency of the United States Government. Neither the United States Government nor any agency Thereof, nor any of their employees, makes any warranty, express or implied, or assumes any legal liability or responsibility for the accuracy, completeness, or usefulness of any information, apparatus, product, or process disclosed, or represents that its use would not infringe privately owned rights. Reference herein to any specific commercial product, process, or service by trade name, trademark, manufacturer, or otherwise does not necessarily constitute or imply its endorsement, recommendation, or favoring by the United States Government or any agency thereof. The views and opinions of authors expressed herein do not necessarily state or reflect those of the United States Government or any agency thereof. 


\section{DISCLAIMER}

Portions of this document may be illegible in electronic image products. Images are produced from the best available original document. 
An Afrimative Action/Equal Opportunity Employer

This report was not edited by the Technical Information staff.

This work was supported by the US Department of Energy, Division of Geothermal Energy. Contract No. L69-49568.

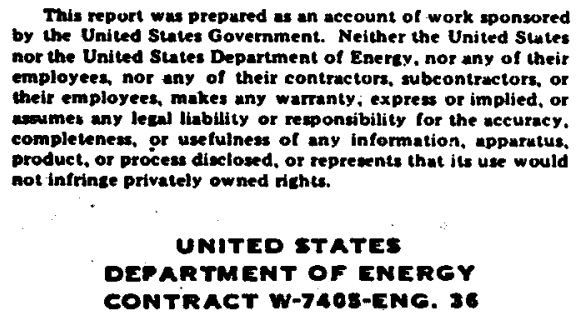




\title{
Geophysical Lineaments of Arizona
}

\author{
L. K. Lepley*
}

*8841 North Calle Loma Lunda, Tucson, AZ 85704.

$$
\begin{aligned}
& \text { This report was prepared a an eccount of work } \\
& \text { sponsored by the United States Govermment. Noither the } \\
& \text { United states nor the United Siales Department of } \\
& \text { Energy, nor any of their omployets, nor any of their } \\
& \text { contractors, subcontracton, of their employees, makes } \\
& \text { any warranty, express or inplied, or asumes any beal } \\
& \text { liability or responsibility for the wecuracy, completeness } \\
& \text { or usefulnews of any information, apparatus, product or } \\
& \text { procese discloved, or represents that its use would not }
\end{aligned}
$$
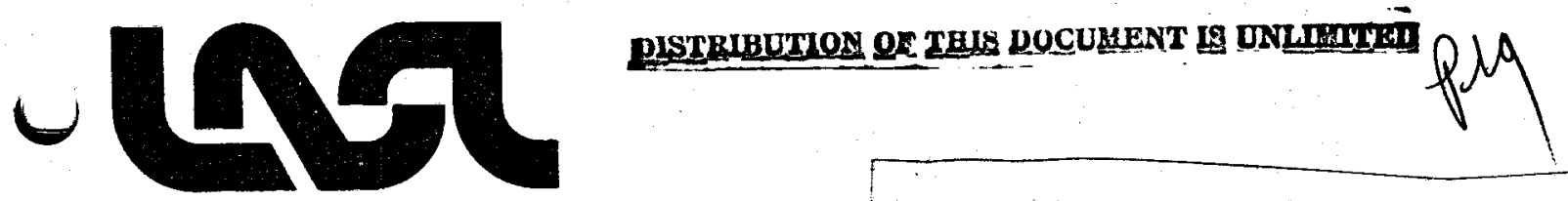
GEOPHYSICAL LINEAMENTS OF ARIZONA

by

L. K. Lepley

\begin{abstract}
Photolineaments seen on satellite images are usually expressions of deep crustal ruptures. However, photol ineaments are omnipresent and an independent expression of regional discontinuities is needed to help rank the photol ineaments. Pub1 ished gravity and magnetic contour maps of Arizona were analyzed to produce a single geophysical lineament map to indicate trends of regional basement structures. This map shows that the southwestern quarter of Arizona is dominated by a NNW-ENE orthogonal system whereas the remainder of the state is gridded by a NW-NE system. North-south systems are present throughout the state, as are EW lineaments. Arizona is transected by the WNW Texas Strand, but other shorter systems trending in the "Texas" direction are found throughout the state south of the Strand.

The major lineament systems as seen on Landsat, gravity, and magnetic maps correlate reasonably well with known geotherma1 manifestations. Many other systems are Precambrian, Paleozoic, and/or Mesozoic in age but appear to control the location of Quaternary volcanic systems.
\end{abstract}

\title{
I. INTRODUCTION
}

Regional 1 ineaments, whether seen on satellite photographs, topographic maps, or contours of gravity or magnetic anomalies, have one thing in common: they are more closely related to basement structure than to surface geology. In the search for new geothermal resources, we need to define deep crustal ruptures that provide conduits for magmatic intrusions and vertical water movement. Boundaries of continental subplates showing relative motion within the past three mil1 ion years and the tracks of "hot spots" are good prospect zones. For example, the Geysers Known Geothermal Resource (KGR) is on the 3 million year trace of the Mendocino transform intersection with the San Andreas system. The Salton Sea Cerro Prieto KGRs are on spreading centers and the Yellowstone KGR is on a hot 
spot plume. The Valles Caldera is at the intersection of a possible hot spot track and the actively spreading Rio Grande Rift.

A photolineament map of Arizona was constructed from Landsat images at $1: 1,000,000$ scale (Lepley 1977) and a lineament map of Arizona at 1:500,000 scale was interpreted from Skylab photographs (Lepley 1978). However, fracture zones and other lineaments are pervasive on satellite photographs and an independent data source is needed to help separate out the fundamental crustal ruptures marking plate boundaries and mantle discontinuities. The 1:1,000,000 scale magnetic and gravity contour maps of Arizona (Aiken 1975; Aiken, Schmidt, and Sumner 1975; West and Sumner 1973; Sauck and Sumner 1975) are especially well suited for this purpose.

The magnetic and gravity anomaly contour maps listed above were analyzed in combination to produce the Geophysical Lineament Map (Fig. 1). The Geophysical Lineament Systems Map (Fig. 2) was derived from the Geophysical Lineament Map. Figures 1 and 2 were constructed for their use with the two satellite photolineament maps to delineate major zones of Quaternary crustal ruptures associated with known geothermal manifest actions (report in preparation: Lepley 1978).

\section{BACKGROUND}

Sauck (1972), in his analysis of the first statewide Arizona aeromagnetic map, noted that regional magnetic 1 ineaments cut across Basin and Range structure and are usually not related to mapped surface geology. He noted that the magnetic lineaments do, however, delineate known Precambrian basement structures on the Plateau. Sauck's analysis of his magnetic lineaments will be discussed below under Results. West (1972) separated the Basin and Range province from the Plateau province on the presence or absence of deep alluvial basin fill defined by gravity anomalies. West found no particularly striking correlation between short wavelength magnetic and gravity patterns but found positive correlations between regional gravity and magnetic trends. Aiken (1976) used harmonic analysis of gravity anomalies to divide Arizona into six provinces wherein the sign of gross regional gravity field is correlated with other deep crustal geophysical data such as seismicity, seismic velocities, deep conductivity, and heat flow.

Stewart and others (1977) used aeromagnetic anomaly patterns to help define trends of age-dated Cenozoic igneous rocks in Nevada. Ekren and others (1976) used Landsat photographs, raised relief maps, aeromagnetic maps, and surface lithology to define lineaments that are the result of deep-seated regional faulting in southern Nevada.

Sumner (1972) used aeromagnetic and gravity trends to trace the southeastern extension of the San Andreas strike slip fault system beneath the sands of the Gran Desierto of Sonora. The Quaternary Pinacate lava field is located at the intersection of other magnetic trends with the dominant $N 60^{\circ} \mathrm{W}$ trend of this part of Sonora and southwestern Arizona.

Cordell (1978) modeled the regional geophysical setting of the four-state area of Arizona, Utah, Colorado, and New Mexico by his analysis of gravity, aeromagnetic, deep seismic, deep electrical conductivity, regional heat flow, and topographic data. He outlined the areas of regional crustal response to Neogene upper mantle changes. 
III. METHODS

I traced linear features from one aeromagnetic map (Sauck and Sumner 1970), a regional Bouguer anomaly map (West and Sumner 1973), a residual Bouguer gravity anomaly map (Aiken 1975), and a free air gravity anomaly map (Aiken, Schmidt, and Sumner 1975). My criteria for picking linear features were similar to those of Sauck (1972) wherein a linear feature was defined by (1) axes of elongate anomalies, (2) linear margins of elongate anomalies, (3) imaginary 1 ines along offsets of anomaly patterns, and (4) alignment of individual contour closures. I have called these features geophysical lineaments. From this set of maps, I constructed a map of magnetic lineaments and a map of gravity lineaments. I combined these two maps in the following way: Where magnetic and gravity lineaments coincided or in combination produced long regional lineaments, I traced these. I rejected gravity and magnetic patterns that were both weak and nonlinear or those that showed no obvious linear coincidence between the gravity and magnetic patterns.

Several versions of the map were produced at widely spaced times using different techniques. For example, two sets of lineaments intersecting at a shallow angle could also be interpreted as a long, gentle curving sinuous lineament. This philosophy was carried through to produce a geophysical lineament map consisting entirely of arcuate or sinuous lineaments. On the other extreme, all but straight 1 ineaments can be ignored to force a fit to the draftsman's straight edge. Well known regional fault systems such as the San Andreas of the U.S. or the Altin Tagh fault of Tibet are locally straight in many places, but gently curved on a continental scale. Sinuous fault traces are sometimes the results of strike slip following two directions of pre-existing basement fractures--following one, and then the other zone. Regional gravity and magnetic fields are a result of basement structure (or mantie structure, in the case of gravity) more than surface geology. I therefore chose to del ineate intersecting ineaments separately in most cases rather than lose this information by smoothing over these intersections with curved lines.

I used an optical Fourier processor to perform directional filtering on the gravity and aeromagnetic contour maps to yield maps of gradients having given directions. The process is described by Arsenault and others (1974) and Lepley (1977).

Strong or regionally continuous 1 inear patterns that showed good correlation between the geophysical maps were marked with heavy lines; weaker gravitymagnetic concurrences were marked with thinner lines. The result is shown as Fig. 1, the Geophysical Lineament Map. From this map, I classified swarms or groups of 1 ineaments into systems and assigned names to these systems for the purpose of identification and discussion. The Geophysical Lineament Systems Map is shown as Fig. 2 .

\section{DISCUSSION OF RESULTS}

The two maps are best viewed as overlays, with a translucent Fig. 1 placed over an opaque Fig. 2. The geophysical lineaments of Fig. 1 will be discussed as systems named on Fig. 2.

Some regular directional and spacial distribution of gravity-magnetic 1 ineament systems are apparent. Over most of the state, two orthogonal sets are present, NW-NE and NS-EW. Within the NW-NE set, the NW systems are spaced at approximately $150 \mathrm{~km}$ between the NW Houserock, Cottonwood, and Tucson systems 
and the NE systems that include the Grand Wash, Sinyala, Bright Angel, Mesa Butte, Greasewood, and $\mathrm{Cl}$ ifton systems are spaced at an average distance of $80 \mathrm{~km}$. North-south systems include the Shylock and Klondike systems and eastwest 1 ineament concentrations are the Deshelly, Pinedale, Buckskin, Chandler, and Sil Nakya-Benson systems.

In southwestern Arizona, these two orthogonal sets are replaced by a NNWENE orthogonal set. The NNW San Andreas system has a quasi-periodical spacing of approximately $35 \mathrm{~km}$ and the ENE Gila Trough and Pinacate systems are about $100 \mathrm{~km}$ apart.

The largest geophysical lineament system in Arizona is the northwesterly cottonwood system. It is 40 to $80 \mathrm{~km}$ wide and extends more than $600 \mathrm{~km}$ in length arching slightly concave to the south, trending $N 40^{\circ} \mathrm{W}$ at the New Mexico border and $N 45^{\circ} \mathrm{W}$ to $N 50^{\circ} \mathrm{W}$ where it passes into Nevada. The Cottonwood system marks West's (1972) proposed Basin and Range-Plateau boundary and an upper mantle conductivity boundary as shown by Cordell's (1978) Fig. 8, where higher conductivity is on the south.

It is informative to compare the geophysical 1 ineament Figs. 1 and 2 to Figs. 3-6 (Pierce 1976) showing Paleozoic basins in Arizona. The Cambrian Defiance positive corresponds to the Pinedale EW system. The Devonian Oraibi trough fits the large gravity high block bounded by the Mesa Butte, Greasewood, and Cottonwood lineament systems. The Permian basin on the Plateau is flanked on the south by the Pinedale system, Fig. 7 .

In southeastern Arizona, the Mesozoic Bisbee formation, Fig. 8 (from Titley 1976) is bounded on the north at $32^{\circ} \mathrm{N}$ latitude by the Benson lineament system and on the west at about $111^{\circ} \mathrm{W}$ longitude by the NW trending Sawmil1 Canyon member of the Tucson system. Spencer Titley's six northwest discontinuities are matched fairly well by the trend of the Tucson geophysical lineament system. The axis of the Paleozoic isopach (Fig. 9) follows the Swisshelm member of the Tucson system. Titley's Paleozoic facies map (Fig. 10) could be interpreted as showing $100 \mathrm{~km}$ left lateral offset along the Benson system. Titley speculates that the WNW Texas zone is composed of minor left lateral offsets along numerous EW and NW faults developing composite WNW movement. Drewes (1976) shows the north edge of the Mesozoic Hidalgo-thrust sheets trending at EW $32^{\circ}$ latitude along the Benson lineament system (Fig. 11). He also shows a postthrust, late Laramide left lateral tear fault extending EW at approximately $31^{\circ} 30^{\prime}$ latitude.

According to Eberly and Stanley (1978) the Gila Trough predates the late Miocene $12-13 \mathrm{~m} . y$. block faulting and was probably associated with mid-Tertiary 28 to $17 \mathrm{~m} . \mathrm{y}$. tectonism. East of the Bosque lineament, the Gila Trough forms a boundary between the more "oceanic" residual Bouguer and gravity magnetic high to the south in the Tucson system and more continental gravity and magnetic lows to the north. To the west of the Bosque lineament, the continuous geophysical alignments of the Gila Trough can be traced ESE along the present Gila River to the San Andreas lineament No. 2. However, an examination of the aeromagnetic map (Sauck and Sumner 1970) shows that the residual magnetic low associated with the trough is offset in a right lateral sense, especially along Nos. 1-3. An examination of the residual Bouguer gravity anomaly map (Aiken 1975) shows the same sense of offset. Combining the two maps, I have estimated the following left lateral offset distances: No. 1 moved $20 \mathrm{~km}$, No. 2 moved $25 \mathrm{~km}$, and No. 3 moved $20 \mathrm{~km}$. The present 1 ineament extension may be due to rejuvenated motion along the main axis of the trough.

West-northwest systems including the Crater Mountain system seem to cut across the San Andreas system. This is illusory due to the small angle of intersection. A close inspection of the magnetic map indicates the possibility of 
similar right lateral offsets of these systems also. The Quaternary Pinacate lava fieid lies at the three-way intersection of the No. 2 San Andreas lineament, the Pinacate system, and a WNW system lying just south of the Arizona-Sonora border. These lineaments were traced from the maps of Sumner (1972).

The Buckskin system, and especially the branch extending west across the Colorado River near Parker, may be related to the present left lateral movement along EW faults in the Transverse ranges due west in California.

The observed magnetic anomaly of the Bright Angel fault is much too great for the observed $70 \mathrm{~m}$ vertical throw of Paleozoic rocks (Sauck 1972). The anomaly here must be generated by the Precambrian rocks below. The northeasterly Sinyala, Bright Angel, and Mesa Butte systems are, according to Shoemaker and others (1974) and Warner (1978), part of a right latera1, middle Precambrian wrench fault system that extends from Arizona to Minnesota. Gravity and aeromagnetic data with radiometric ages from deep wells were used by Warner to del ineate a pattern resembling the San Andreas fault system that trends roughly parallel to the regional grain of the basement rocks.

Sauck notes that the east-west magnetic low under Black Mesa (De Chelly) indicates a computed $3.5 \mathrm{~km}$ normal fault in basement rocks. He al so notes that directly beneath the San Francisco Mountains is an EW magnetic low (actually the ENE Humphry lineament; that the Calderas of the Superstitions 1 ie on the intersection of a NE lineament with an EW magnetic low (Chandler); and the Turkey Creek Caldera is at an intersection of a NE lineament with a NW (Swisshelm) 1 ineament.

Aiken (1976), in his Fourier analysis of gravity data to quantitatively define broad patterns, found that Arizona is divided into two domains of regional gravity (Fig. 12). The northeastern half of Arizona is dominated by $\mathrm{N} 35^{\circ} \mathrm{E}-$ trending highs and lows that are truncated by the $\mathrm{N} 60^{\circ} \mathrm{W}$ system of southwestern Arizona. His NE trending system on the Plateau consists of two highs and two lows. His NW low is a nearly equidimensional gravity low centered over the intersections of the Sinyala and Bright Angel systems with the Cottonwood system of Fig. 2 and follows the Colorado lineament of Warner (1978). Aiken's NE low extends northeast from the Cottonwood lineament system between the Diabase and Clifton systems. This NE low roughly corresponds to Cordell's (1978) Jemez lineament. A NE high lies between the NW low and NE low and his SE high lies east of the $\mathrm{Cl}$ ifton system. In southwestern Arizona, Aiken's regional $\mathrm{N} 60^{\circ} \mathrm{W}$ Tucson-Ajo gravity gradient separates the above systems from his SW low that lies along the Tucson-Ajo gradient. Aiken also compiled maps of deep-sounding geophysical information and related geology that are useful to compare with Fig. 2. For example, the eastern limits of Mesozoic thrusting correspond roughly to the Harquahala. Tucson, and Benson systems (Fig. 13). A Pn velocity trough trends EW at $35^{\circ} \mathrm{N}$ a long the Pinedale system (Fig. 14). Earthquake epicenters are aligned roughly with the Crater Mountain, Cowhide, and Pinacate systems (Fig. 15). Silicic volcanism is found on a line that extends ESE from the Humphry Tineament (Fig. 16). Sauck (1972) has constructed a set of directional histogram rosettes of total 1 ine lengths of magnetic 1 ineaments. He divided Arizona into four provinces for the purpose of compiling the rosettes: NW, NE, SW, and SE. The Cottonwood 1 ineament system approximates his division between his two northern and two southern quadrants. The northern quadrants are dominated by a northeast grain consisting of mostly $N 40^{\circ} \mathrm{E}$ and $N 60^{\circ} \mathrm{E}$ trends and by EW 1 ineaments. The southern quadrants are dominated by an array of northwesterly trends, predominantly $\mathrm{N} 35^{\circ} \mathrm{W}, \mathrm{N} 60^{\circ} \mathrm{W}$, and $\mathrm{N} 80^{\circ} \mathrm{W}$, and an $\mathrm{EW}$ ( $\mathrm{N} 80^{\circ} \mathrm{E}$ ) trend. All quadrants have sharpiy defined NS systems: 
The Grand Wash, Cottonwood, and $\mathrm{Cl}$ ifton lineament systems are concurrent with the borders of the lower electrical conductivity of the upper mantle under the Plateau (Cordell 1978). The Arizona strip west of the Grand Wash lineament includes the zone of highest conductivity and high heat flow associated with the wasatch front. Cordell used aeromagnetic data to show the conjugate gridded structural grain of the basement that has controlled Quaternary rifting. Gravity data shows graben border faults, Precambrian basement structural grain, and deep crustal and upper mantle structure all superimposed. Cordell attributes the broad regional topographic and gravity buoyant response to Neogene upper mantle changes. The regional gravity low east of the Greasewood and northeast of the Cottonwood system he considers to be part of a basement cored horst responding to those changes.

The Texas Strand lineament was so named because this system is only one of several strands trending in the famous WWW "Texas" direction. The Texas Strand is not only an alignment of Bouguer gravity and aeromagnetic gradients, but is a boundary between textural provinces on Sauck and Sumner's aeromagnetic map. North of the lineament, magnetic relief is typically 800 gammas and a typical gradient is 160 gammas per $\mathrm{km}$. South of the Texas Strand typical magnetic relief and gradients are 300 gammas and 20 gammas per $\mathrm{km}$, respectively. This 1 ineament also marks the southern edge of the large negative residual Bouguer anomaly (Groom Peak) shown on Aiken's 1975 map and the most intense part of the large positive magnetic anomaly of the Chandler system.

\section{PRELIMINARY CONCLUSIONS}

The purpose of the construction of the geophysical lineament map was to provide an independent set of data relating to fundamental basement and mantle structure to compare with the maps of satellite photolineaments, because the Landsat lineaments (Lepley 1977) and Skylab lineaments (Lepley 1978) are believed to be surface expressions of deep crustal structure. Reference should also be made to the geothermal map by Hahman and others (1978). Certain conclusions may be drawn from this work that are pertinent to geothermal exploration.

(1) The Hidden Canyon lineament may be one of a series of ENE to NE rightlateral (in Arizona) transform faults related to the present spreading of the Great Basin.

(2) The San Francisco volcanic field at $35^{\circ} 00^{\prime}$ to $35^{\circ} 30^{\prime} \mathrm{N}, 11^{\circ} 30^{\prime}$ to $112^{\circ}-00^{\circ} \mathrm{W}$, is bounded on the west by the Mesa Butte and Cottonwood systems and Humphrys Peak is split by the Humphrys lineament.

(3) The San Bernadino volcanic field, at $31^{\circ} 30^{\prime} \mathrm{N}, 109^{\circ} 15^{\prime} \mathrm{W}$ lies within an extension of the Swisshelm system, and the Lightning Dock KGR is bounded by an easterly extension of the Benson system.

(4) The series of hot springs extending NE from Tucson to Clifton seems to be controlled by lineaments of the Clifton system.

(5) Where lateral motion can be deduced for the NS systems, it is consistently right-lateral in sense. A row of hot springs lies on the eastern edge of the Shylock NS system.

(6) Known geothermal manifestations occur in or adjacent to the Gila Trough and Chandler systems.

(7) The Texas Strand lineament system might be used as a southern geophysical border of the Colorado Plateau, because it marks a contrast in magnetic texture signifying a difference in the deeper crust. For example, the Curie depth is probably shatlower south of the Strand. 
In conclusion, the major 1 ineament systems as seen on Landsat, gravity, and magnetic maps correlate reasonably well with known geothermal manifestations. Many major systems are Precambrian, Paleozoic, and/or Mesozoic in age but appear to control the location of Quaternary volcanic systems. My conclusions on Quaternary plate boundaries must be reserved for my report on Skylab photolineaments, in preparation:

\section{SUMMARY}

Photolineaments seen on satellite images are usually expressions of deep crustal ruptures. However, photolineaments are omnipresent and an independent expression of regional discontinuities is needed to help rank the photolineaments. Published gravity and magnetic contour maps of Arizona were analyzed to produce a single geophysical lineament map to indicate trends of regional basement structures. This map shows that the southwestern quarter of Arizona is dominated by a NNW-ENE orthogonal system whereas the remaining state is gridded by a NW-NE system. North-south systems are present throughout the state, as are EW 1 ineaments. Arizona is transected by the WNW Texas Strand. but other shorter systems trending in the "Texas" direction are found throughout the state south of the Strand. The geophysical lineament map of Arizona is now being used in the interpretaton of satellite lineaments in a new map derived from 1:500,000 scale color-enhanced Skylab and color infrared Landsat photographs (report in preparation).

\section{REFERENCES}

1. C.L.V. Aiken, "Residual Bouguer Gravity Anomaly Map of Arizona," Laboratory of Geophysics, University of Arizona, Tucson (1975).

2. C.L.V. Aiken, J. S. Schmidt, and J. S. Sumner, "Free-Air Gravity Anomaiy Map of Arizona," Laboratory of Geophysics, University of Arizona, Tucson (1975).

3. C.L.V. Aiken, "The Analysis of the Gravity Anomalies of Arizona," diss., University of Arizona, Tucson (1976).

4. H. H. Arsenault, M. K. Sequin, and N. Brousseau, "Optical Filtering of Aeromagnetic Maps," Appl ied Optics, v. 13, p. 1013.

5. L. Corde11, "Regional Geophysical Setting of the Rio Grande Rift," Geol. Soc. Amer. Bull., v. 89, p. 1073-1090 (1978).

6. H. Drewes, "Laramide Tectonics from Paradise to Hell's Gate, Southwestern Arizona," Arizona Geol. Soc. Digest, v. X, p. 151-167.

7. L. D. Eberly and T. B. Stanley, Jr., "Cenozoic Stratigraphy and Geologic History of Southwestern Arizona," Geol. Soc. Amer. Bu11., v. 89, p. 921940.

8. E. B. Ekren, R. C. Buckham, W. J. Carr, G. L. Dixon, and W. D. Quinlivan, "East-Trending Structural Lineaments in Central Nevada," US Geol. Surv., Prof. Paper 986. 
9. W. R. Hahman, C. Stone, J. C. Witcher, "Prel iminary Map of Geothermal Energy Resources of Arizona: Geothermal Map No. 1, Arizona Bureau of Geology and Mineral Resources, Tucson (1978).

10. L. K. Lepley, "Landsat Lineament Map of Arizona with Emphasis on Quaternary Fractures," Report prepared for Arizona Bureau of Geology and Mineral Technology, Tucson, p. 25 (one map and 13 figures) (1977).

11. L. K. Lepley, "Skylab Lineament Map of Arizona, in preparation (1978).

12. H. W. Pierce, Elements of Paleozoic Tectonics in Arizona, Arizona Geol. Soc. Digest, V. X, p. 37-57.

13. W. A. Sauck and J. S. Sumner, "Residual Aeromagnetic Map of Arizona," Laboratory of Geophysics, University of Arizona, Tucson (1970).

14. W. A. Sauck, "Compilation and Prel iminary Interpretation of the Arizona Aeromagnetic Map," PhD diss., University of Arizona, Tucson (1972).

15. E. M. Shoemaker, R. L. Squires, and M. J. Abrams, "The Bright Angel and Mesa Butte Fault Systems of Northern Arizona, in Karlstrom and Others," Geology of Northern Arizona: Part I, Regional studies: Geol. Soc. America, Cordilleran Sec. Mtg., Flagstaff, Ariz., p. 355-391 (1974).

16. J. H. Stewart, W. H. Moore, and I. Zietz, "East-West Patterns of Cenozoic Igneous Rocks, Aeromagnetic Anomalies, and Mineral Deposits, Nevada and Utah," Geol. Soc. Amer. Bu11., v. 88, p. 67-77 (1977).

17. J. R. Sumner, "Tectonic Significance of Gravity and Aeromagnetic Investigations at the Head of the Gulf of California," Geol. Soc. Amer. Bul1., v. 83, p. 3103-3120 (1972).

18. S. R. Titley, "Evidence for a Mesozoic Linear Tectonic Pattern in Southeastern Arizona," Arizona Geol. Soc. Digest, v. X, p. 71-101 (1976).

19. L. A. Warner, "The Colorado Lineament: A Middle Precambrian Wrench Fault System," Geo1. Soc. Amer. Bu11., v. 89, p. 161-171 (1978).

20. R. E. West, "A Regional Bouguer Gravity Anomaly Map of Arizona," PhD diss., University of Arizona, Tucson, p. 186 (1972).

21. R. E. West and J. S. Sumner, "Bouguer Gravity Anomaly Map of Arizona," Laboratory of Geophysics, University of Arizona, Tucson (1973). 


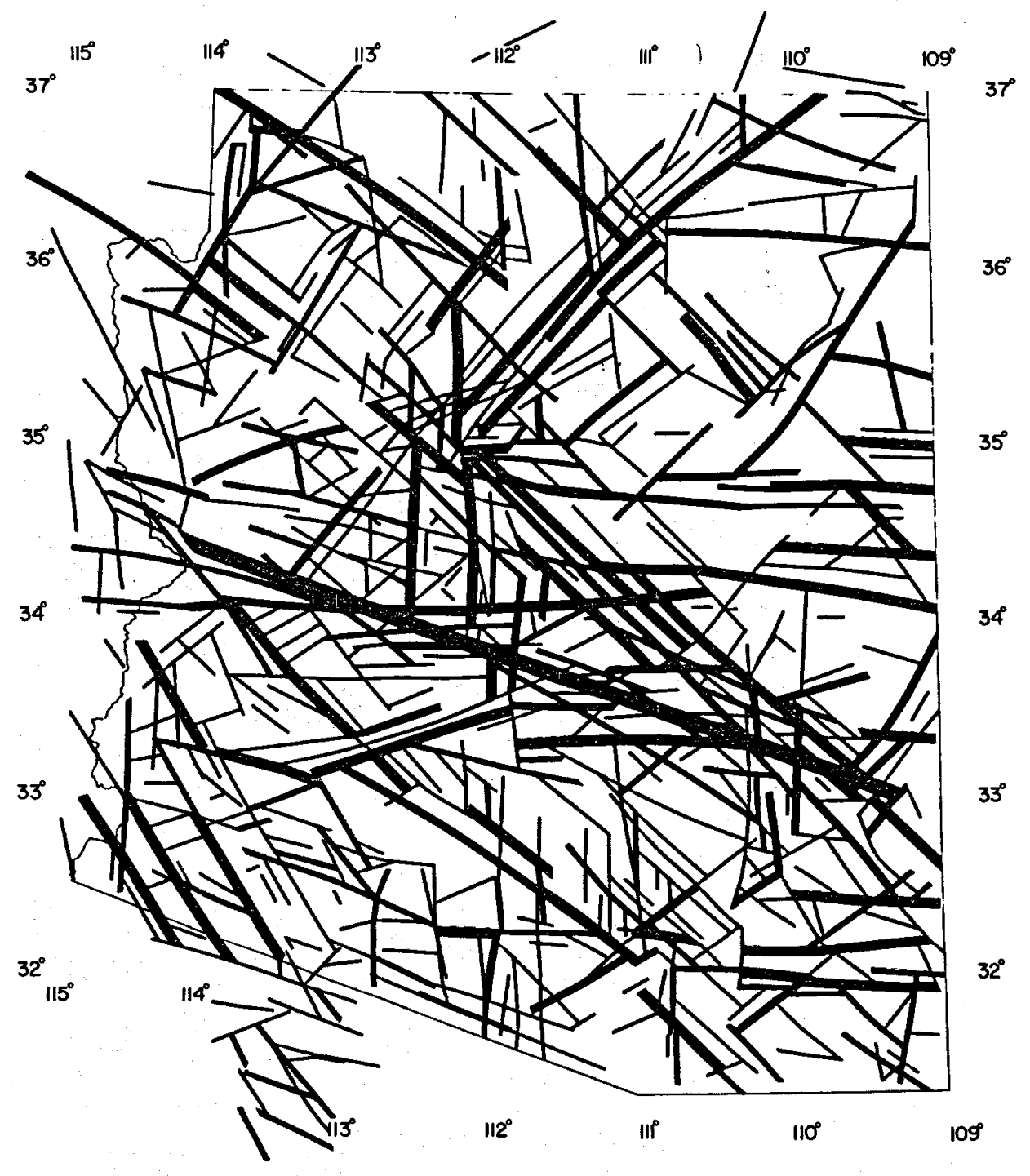

Fig. 1.

Geophysical lineament systems. (Full-sized map in pocket on inside back cover.) 


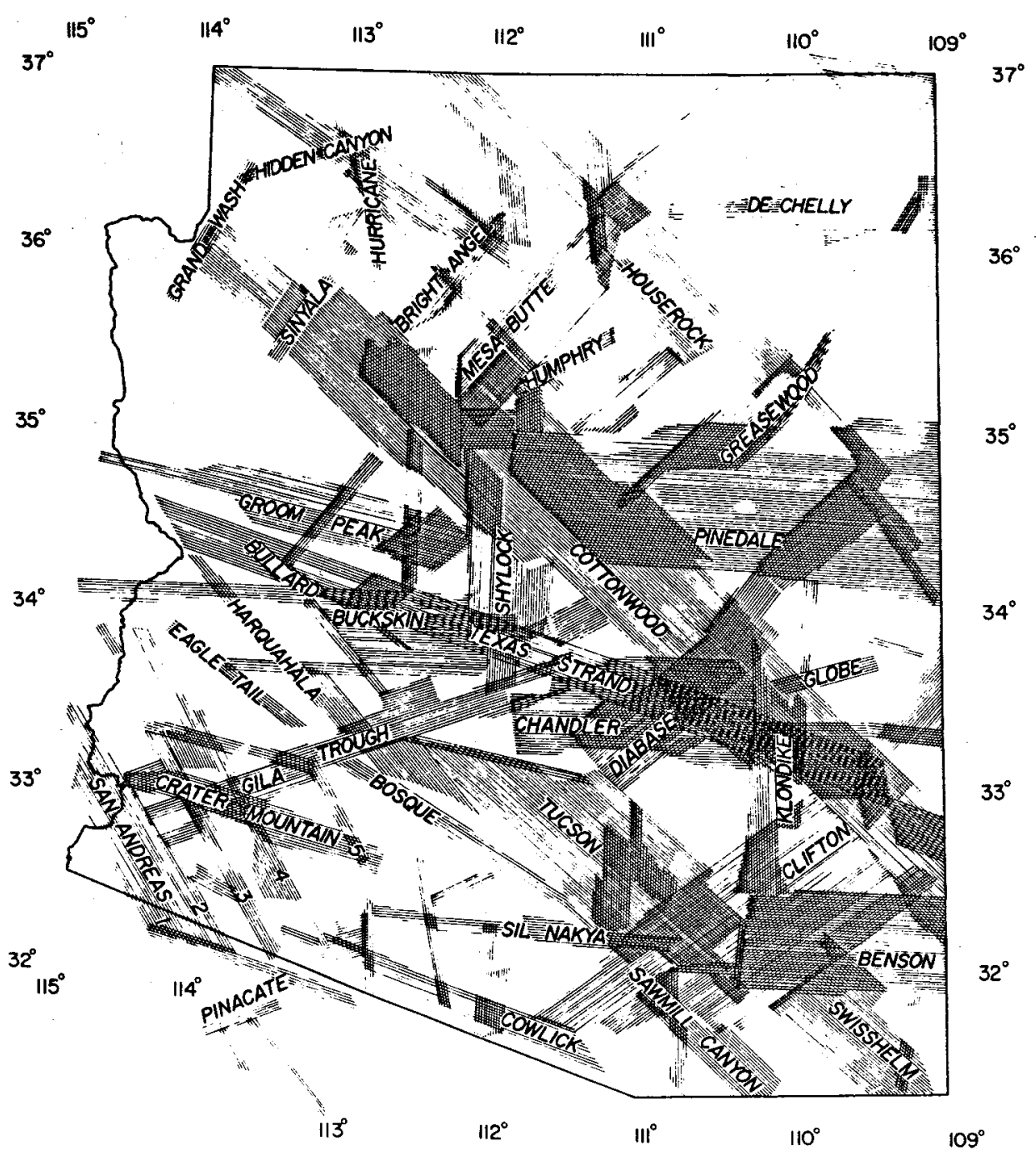

Fig. 2 .

Geophysical lineament systems. (Full-sized map in pocket on inside back cover). 


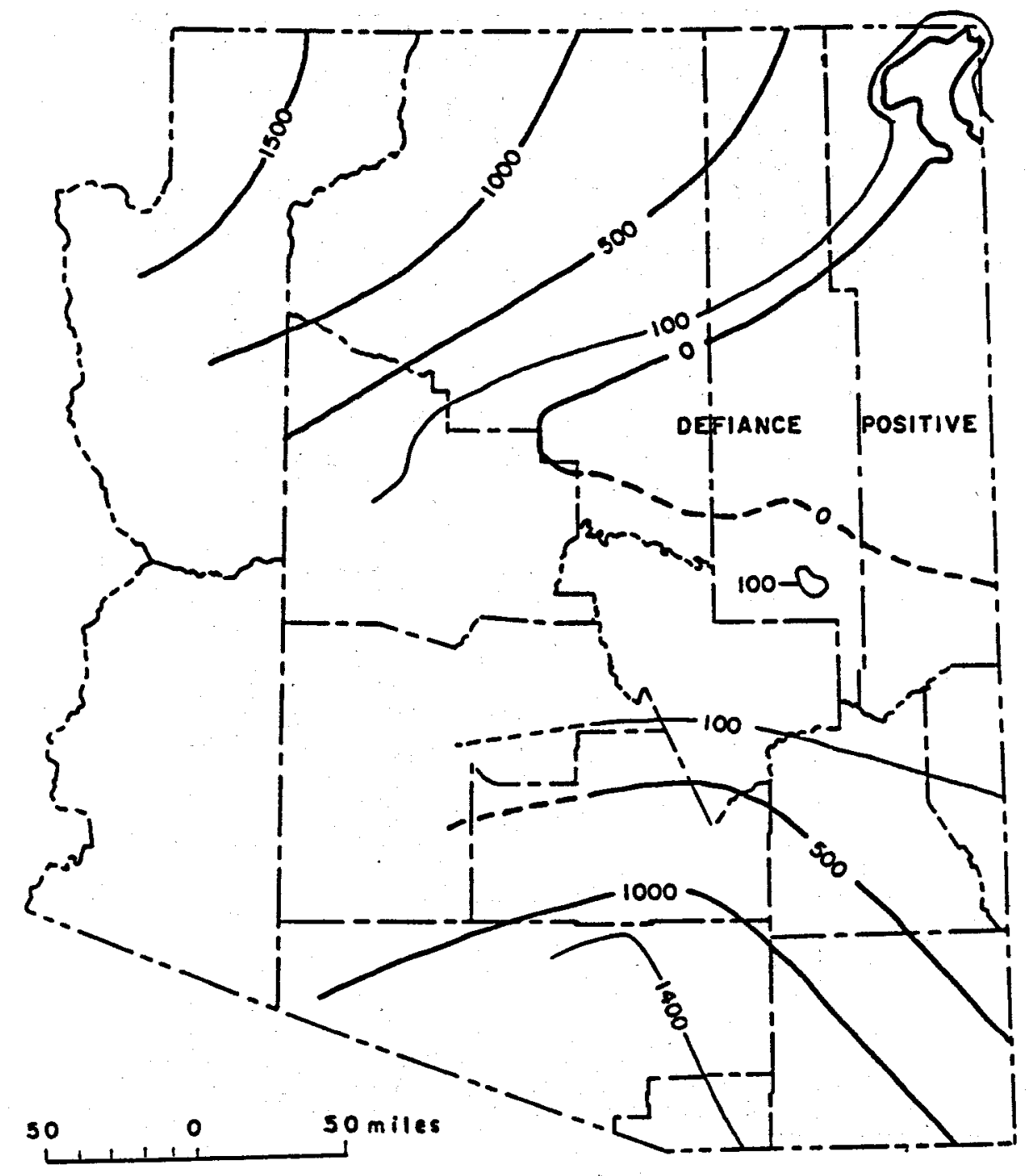

Fig. 3 .

Generalized isopach of the Cambrian System (Peirce 1976). 


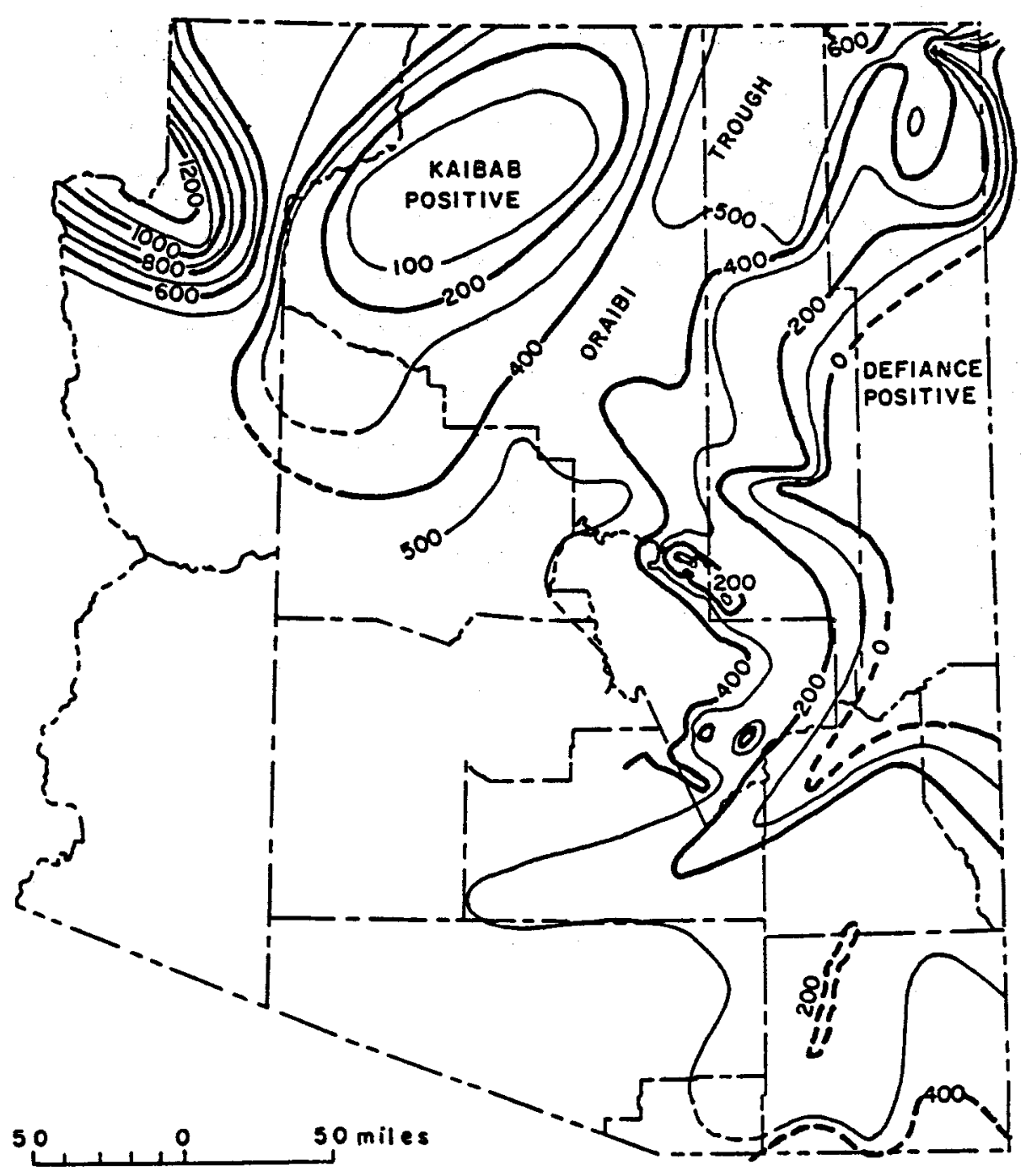

Fig. 4.

Generalized isopach of the Devonian System (Peirce 1976). 


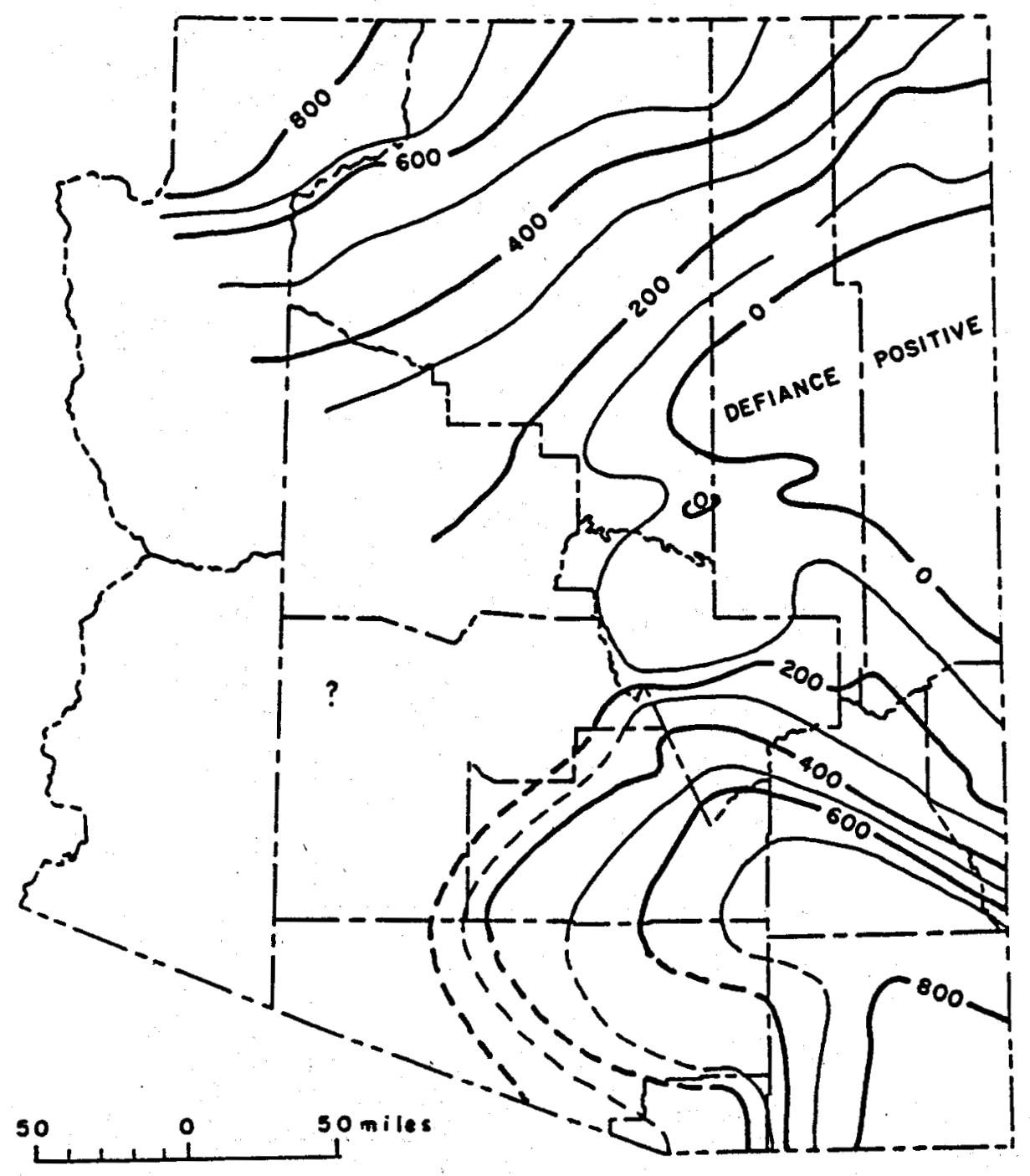

Fig. 5 .

Generalized isopach of the Mississippian System (Peirce 1976). 


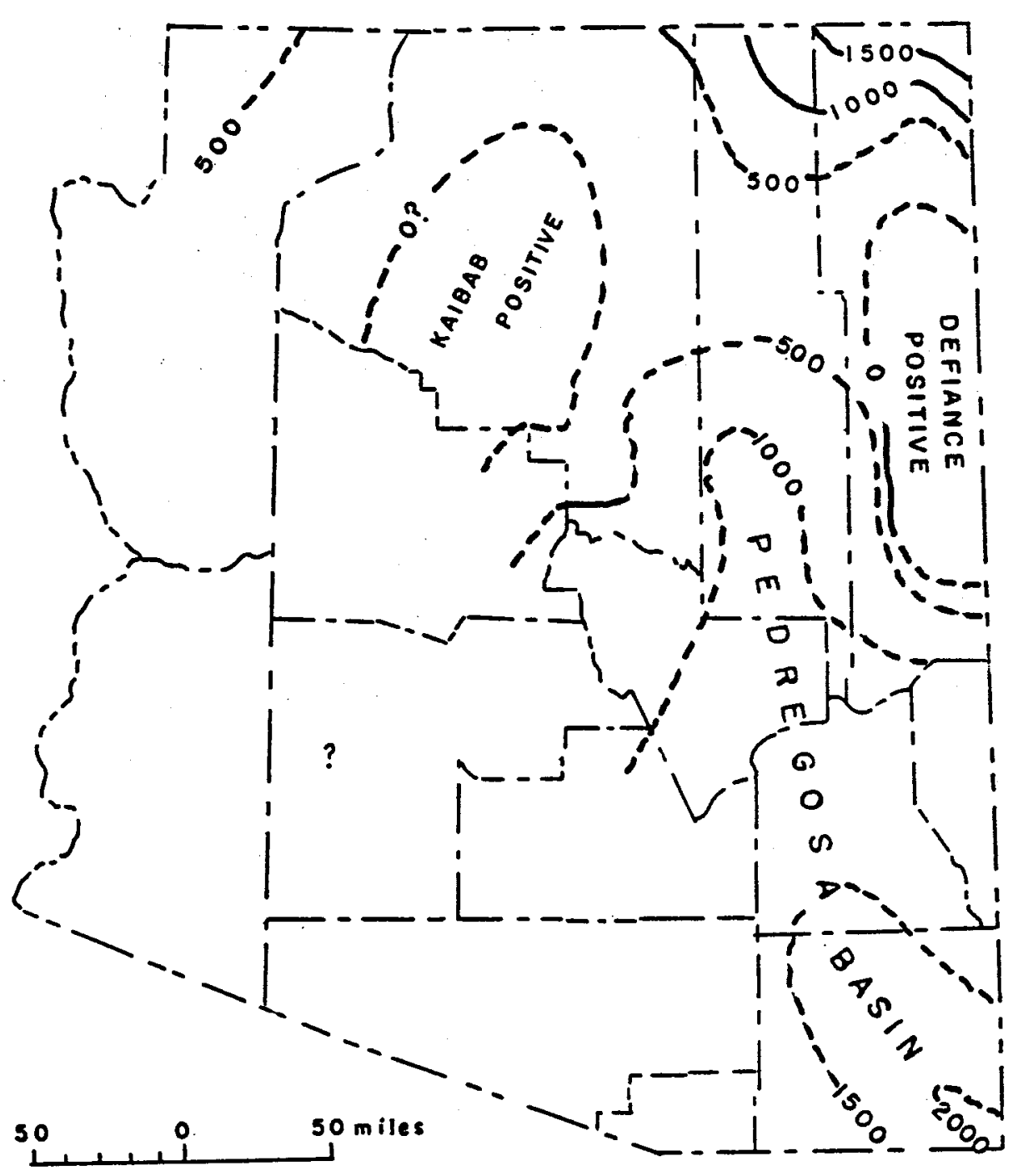

Fig. 6.

Generalized isopach of the Pennsylvanian System (Peirce 1976). 


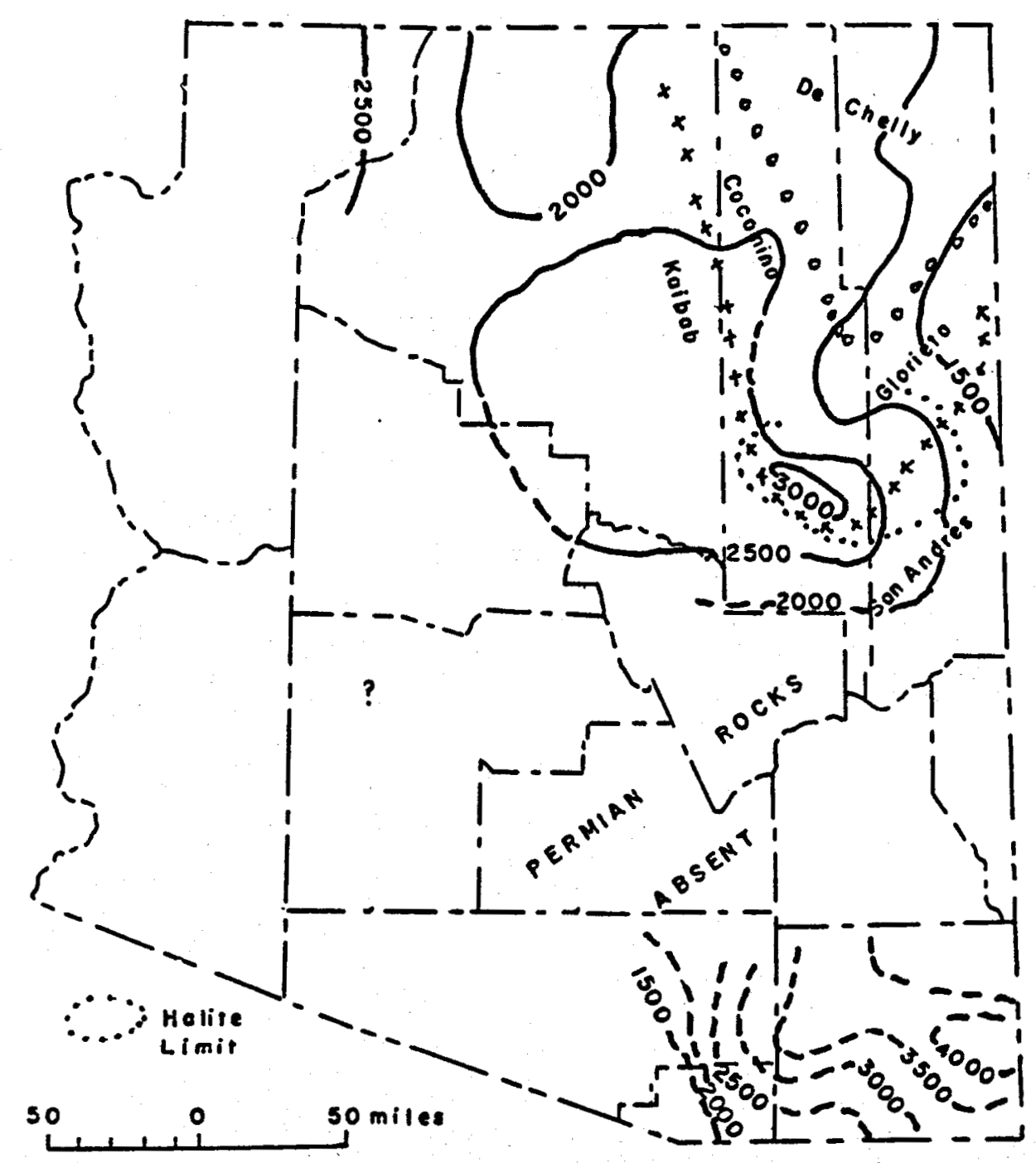

Fig. 7.

Generalized isopach of the Permian System (Peirce 1976). 


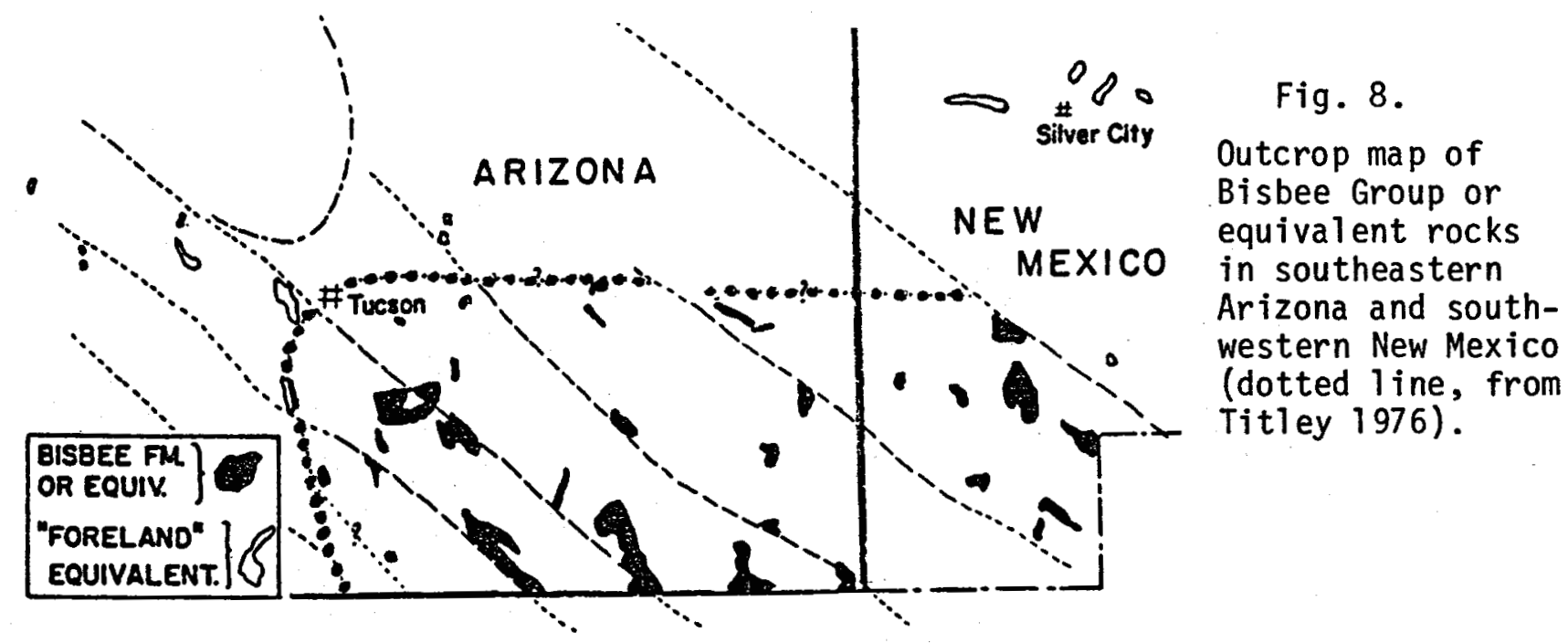

Fig. 9.

Paleozoic isopach map of southern Arizona and adjoining New Mexico. Modified from Peirce and Wilt (1971) and Mckee (1951). (Titley 1976).
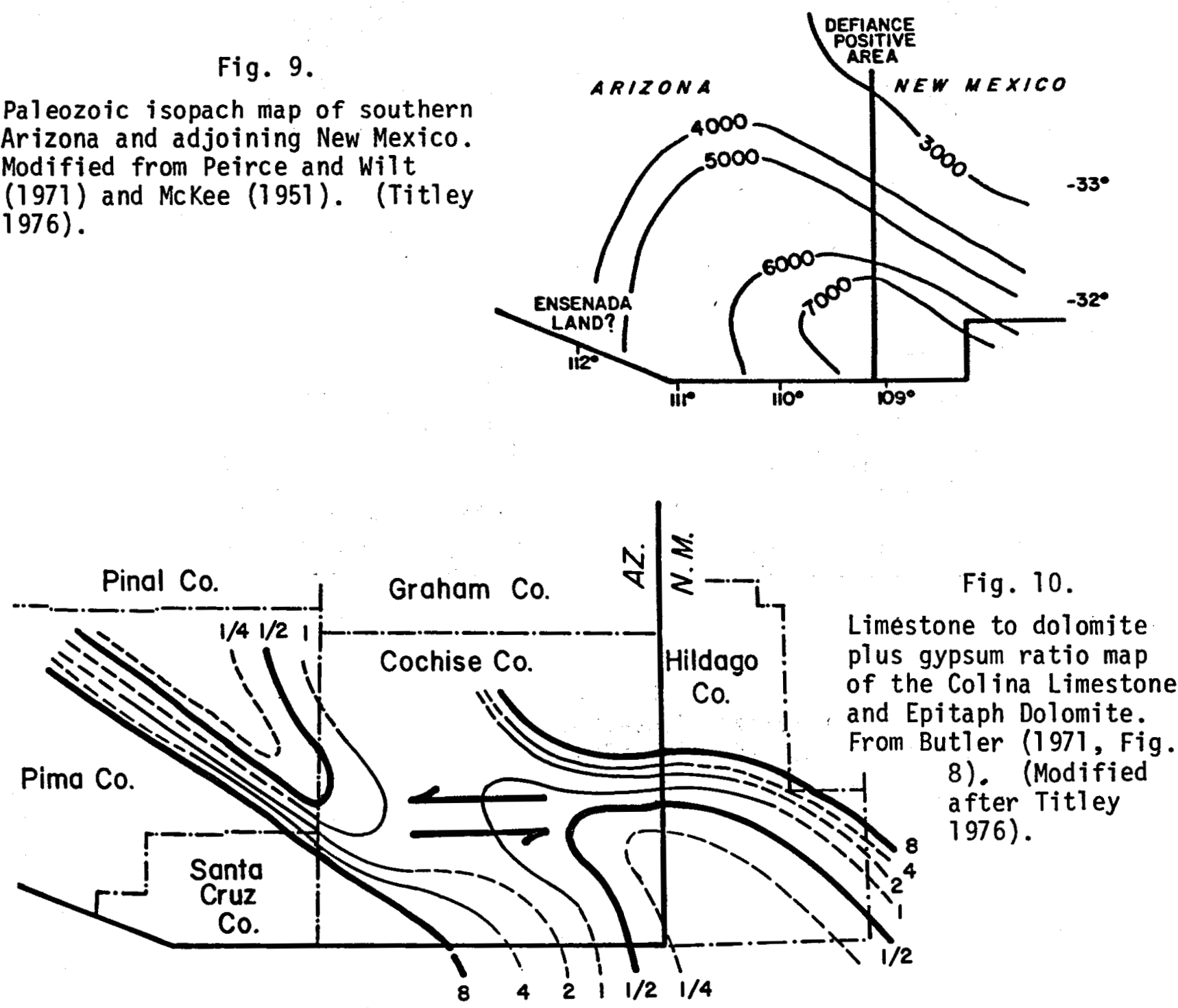



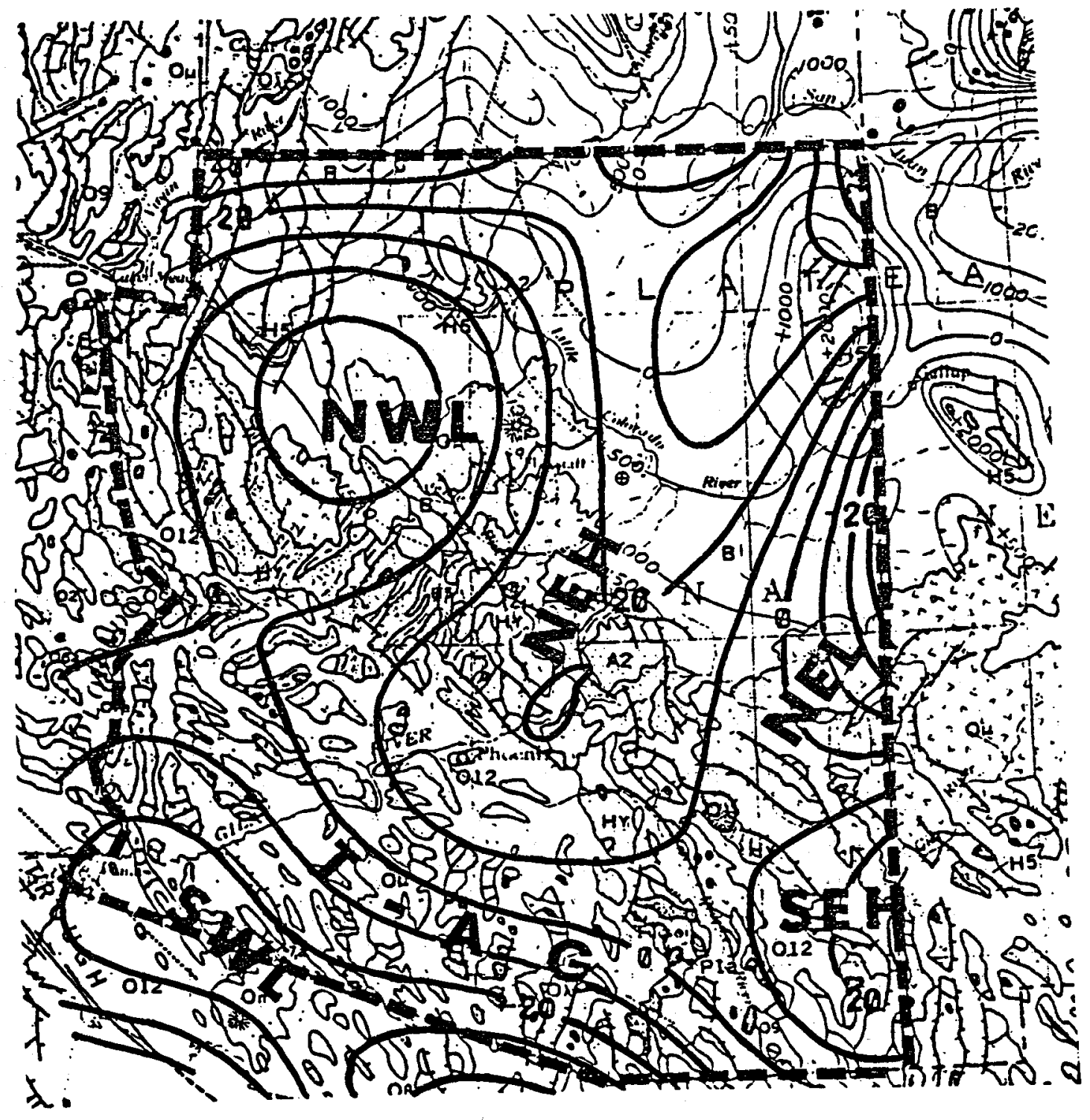

Fig. 12.

First two-harmonic trend surface of residual Bouguer gravity anomalies (Aiken 1976). 


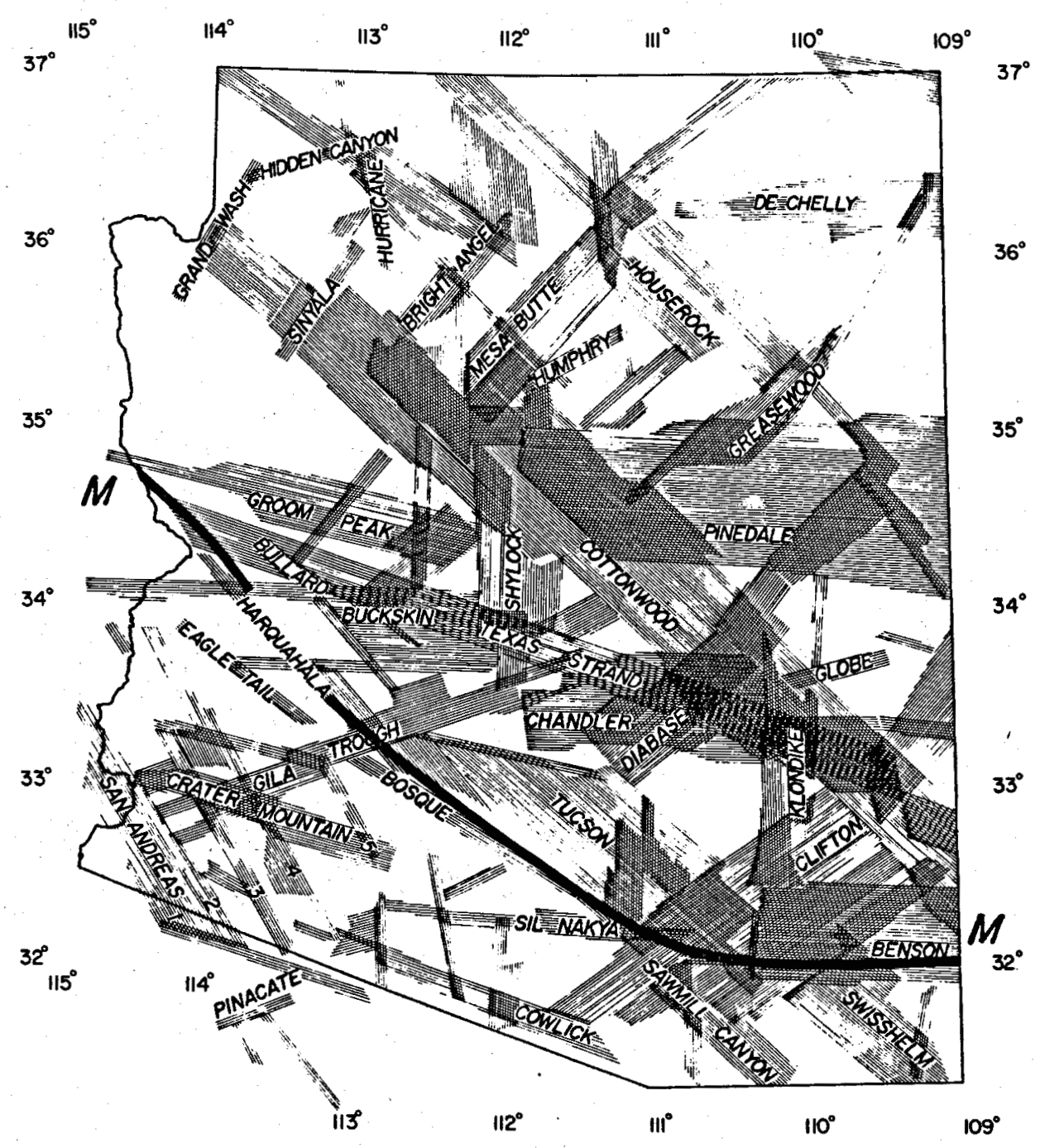

Fig. 13.

Line $M$ denotes the eastern extent of Mesozoic thrusting. (Lipman and others 1972). 


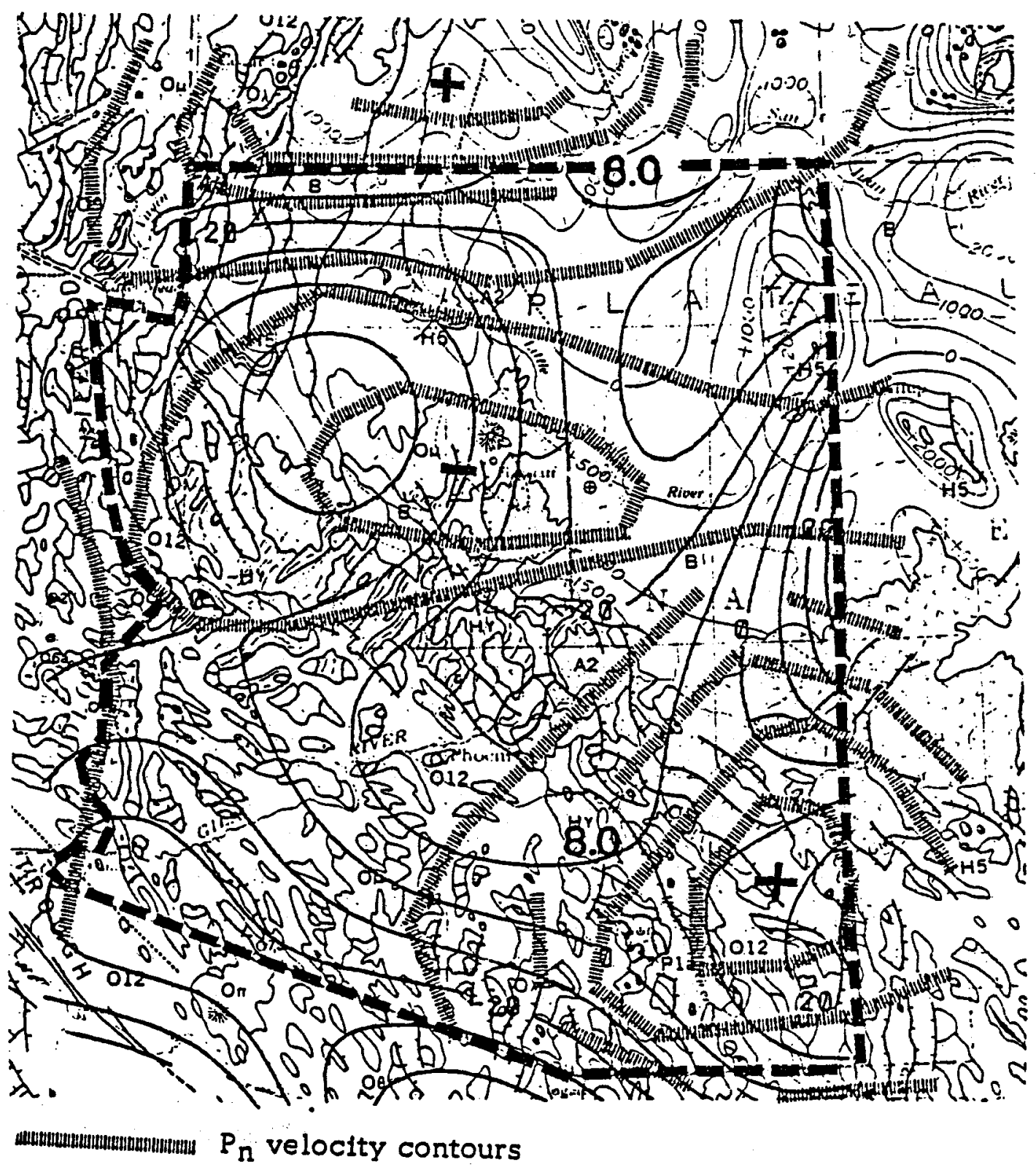

Fig. 14 .

First two-harmonic trend surface of residual Bouguer gravity anomalies and $P_{n}$ velocities. 


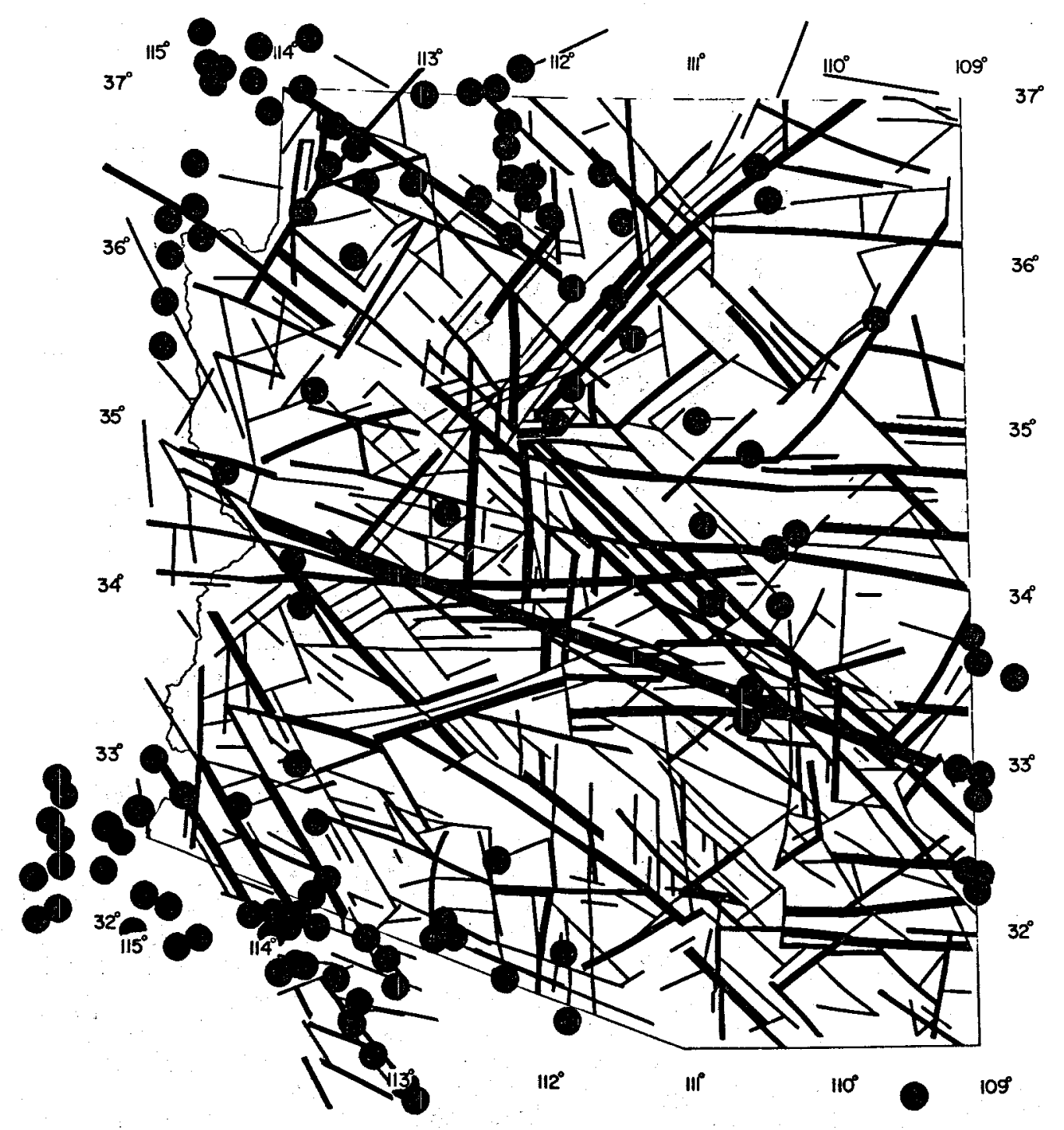

Fig. 15 .

First two-harmonic trend surface of residual Bouguer gravity anomalies and distribution of historical earthquake epicenters (Aiken 1976). 


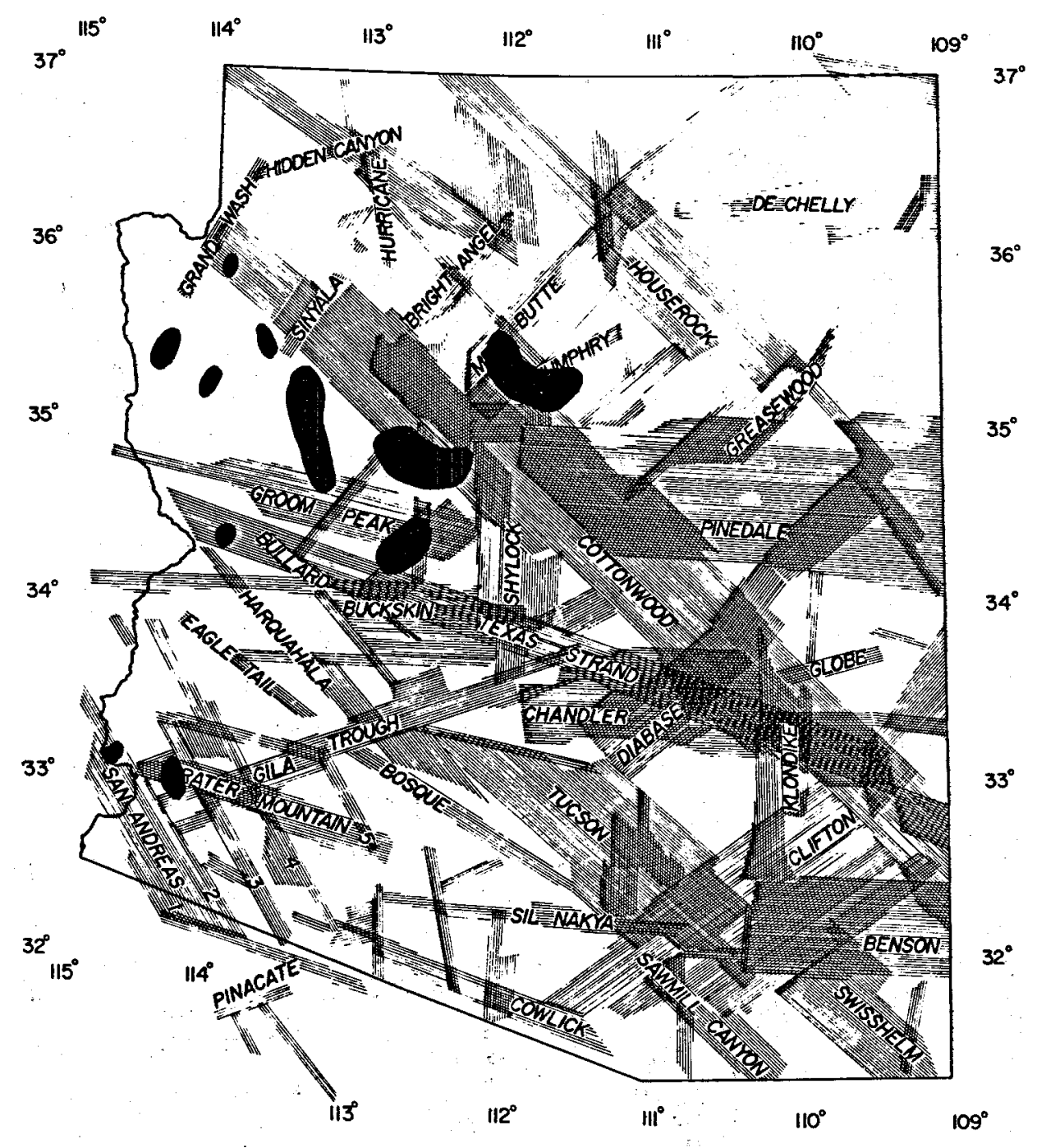

Fig. 16.

Silicic Cenozoic volcanics (Aiken 1976). 


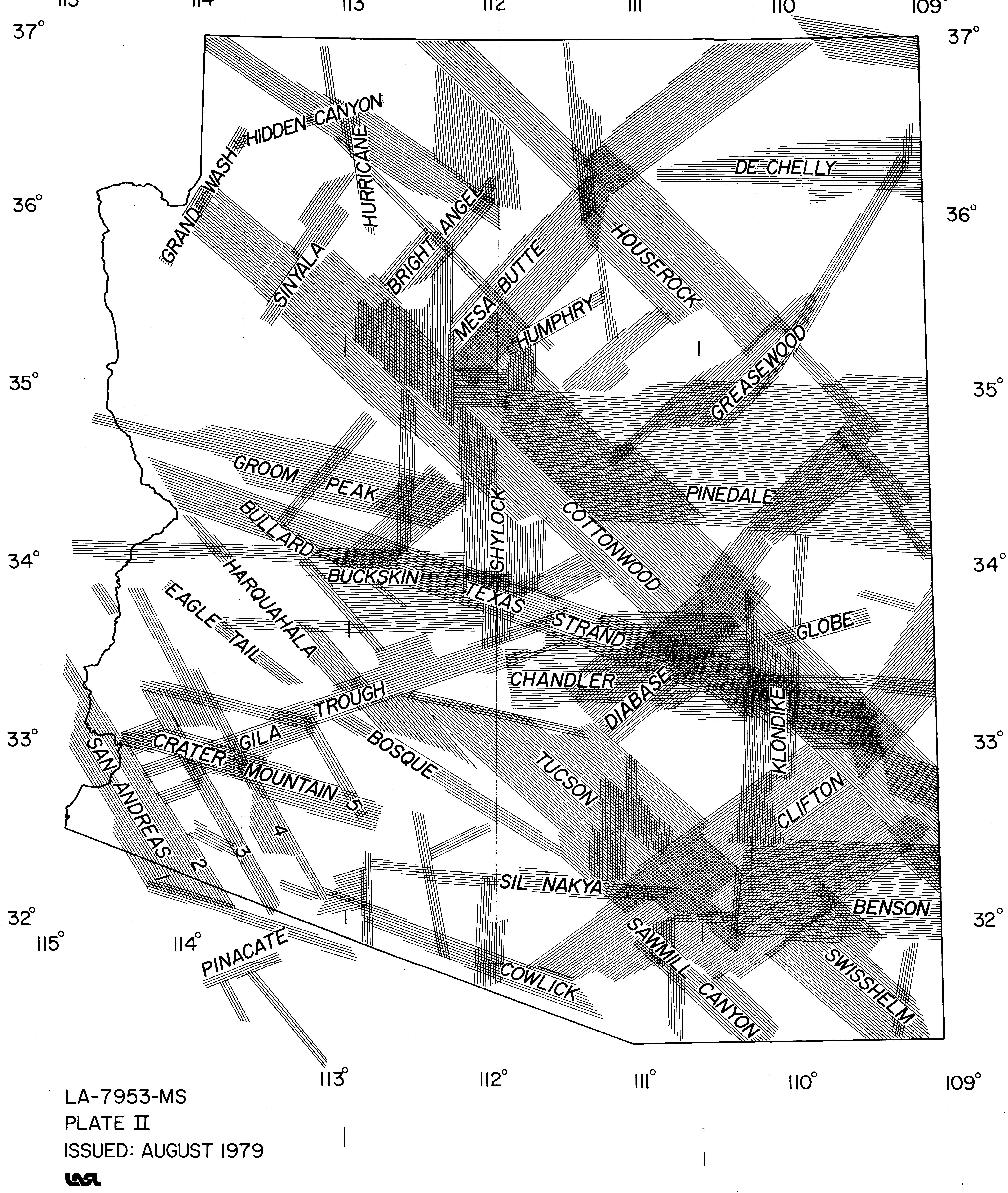

